\title{
NEW DOVYALICIN-TYPE SPERMIDINE ALKALOID FROM DOVYALIS CAFFRA (WARB.); FAMILY: SALICACEAE, CULTIVATED IN EGYPT \\ Mohammed A. A. Zaki ${ }^{* 1}$, Mostafa M. Hegazy ${ }^{1}$, Ahmed B. M. Mehany ${ }^{2}$, Lotfy D. Ismail $^{1}$ and Hazem A. Kadry ${ }^{1}$ \\ ${ }^{1}$ Department of Pharmacognosy, Faculty of Pharmacy, Al-Azhar University, Cairo, Egypt. \\ ${ }^{2}$ Department of Zoology, Faculty of Science, Al-Azhar University, Cairo, Egypt.
}

*Corresponding author: mohammed.zaki.2@azhar.edu.eg

\begin{abstract}
Phytochemical investigations of Dovyalis caffra (leaves and twigs) revealed a new dovyalicin-type spermidine alkaloid, named Dovyalicin G (1); which was identified as (E)-N-(4-(1,5-diazocan-1-yl)butyl)-N-methyltetradec-2-enamide, along with previously isolated $\beta$-sitosterol (2) and Hentriacontan-1-ol (3). The structures were established using ESI/MS, EI/MS, ${ }^{1} \mathrm{H}$ NMR, APT NMR, and two-dimensional NMR experiments. In addition to the biological studies of the different plant extracts including cytotoxicity, topoisomerase II inhibition, antimicrobial, and in-vitro anti-inflammatory activities. Screening of 5-lipoxygenase (5-LOX) and Cyclooxygenase-1 (COX-1) and -2 $(\mathrm{COX}-2)$ inhibition to evaluate anti-inflammatory activity were performed. The alkaloid fraction showed good antimicrobial activity against studied microorganisms and remarkable cytotoxic activities against studied cell lines (Besides, total methanolic and petroleum ether extracts). The total methanolic extract showed strong COX-inhibition activity and selectivity toward COX-2, comparing with celecoxib.
\end{abstract}

Keywords: Dovyalis caffra, anti-inflammatory, alkaloid, cyclooxygenase-1, 5lipoxygenase, dovyalicin $\mathrm{G}$

\section{Introduction}

Dovyalis caffra (Salicaceae) is an erect evergreen shrub or small dioceous tree. D. caffra is native to southern Africa and it is widely cultivated in Egypt as a hedge plant. Formerly, it was classified as a member of a defunct family; Flacourtiaceae, but now it belongs to family Salicaceae under the tribe of Flacourtieae (Chase et al. 2002; Cheek and Ngolan 2006; Chase et al. 2016; Lemke 1988; Steyn, Van Wyk, and Smith 2005). The roots of Dovyalis caffra and other Dovyalis spp. are used in African traditional medicine to treat amenorrhea and chest pain. Also, they are used by the Zulu to treat pain in rheumatic fever and rheumatism (Stanstrup et al. 2010). Recently, the total methanolic extract of the plant (leaves and twigs) was studied for its cytotoxic activity which was promising (Moustafa et al. 2014). Dovyalicin-type alkaloids are a class of amide alkaloids having a spermidine nucleus $\left(\mathrm{NH}_{2}\left(\mathrm{CH}_{2}\right)_{3} \mathrm{NH}\left(\mathrm{CH}_{2}\right)_{4} \mathrm{NH}_{2}\right)$, with at least one nitrogen atom involved in amide group. Till now, this type of alkaloids is exclusively isolated from the genus Dovyalis (D. abyssinica, D. macrocalyx, and D. 
hebecarpa) and six members were identified and named as Dovyalicin A, B, C, D, E, and F (Rasmussen et al. 2006; Stærk et al. 2003). The previous phytochemical studies of D. caffra (Warb.) resulted in the isolation of polyamine alkaloids; aberiamine; and aberiamide, Flavonoids; Luteolin; apigenin; and apigenin-7-O- $\beta$-D-glucopyranoside, triterpenes; $\alpha$ - and $\beta$ - amyrins, sterols; $\beta$-sitosterol; and $\beta$-sitosterol-O- $\beta$-Dglucopyranoside (Sayed et al. 2000), and phenolic glycosides; itoside A; and 4hydorxytremulacin (Stanstrup et al. 2010). Biological investigations were performed on the total extract and showed antimicrobial activities (Zaki 1975), Cytotoxic Activity (Moustafa et al. 2014) and inhibition of proliferation of Hep G2 cells via apoptosis (ElMenshawi et al. 2010).

This study aimed to investigate different biological activities of the extracts with different polarities- of $D$. caffra (Warb.), including cytotoxicity, topoisomerase II inhibition assay, antimicrobial, and in vitro- anti-inflammatory, along with phytochemical investigation of alkaloid and the less polar fractions.

\section{Material and methods:}

\section{Experimental:}

General experimental procedures: ESI/MS spectra were obtained using LC/MS positive and negative modes. NMR spectra were recorded on a Varian Mercury $400 \mathrm{MHz}$ spectrometer at $400\left({ }^{1} \mathrm{H}\right), 100$ (APT) $\mathrm{MHz}$, and 2D (HSQC \& $\mathrm{HMBC}$ ) in $C D C l_{3}$ solution and chemical shifts were expressed in $\delta$ (ppm) with reference to TMS, and coupling constant $(J)$ in Hertz. Column chromatographic separations was performed on silica gel 60 (Si gel 60, Merck), sephadex LH-20 (Pharmacia) and SPE-C-18 (Phenomenex) columns. TLC was performed on precoated TLC plates with silica gel 60 F254 (0.2mm, Merck). Developed chromatograms were visualized by spraying with Vanillin/ $\mathrm{H}_{2} \mathrm{SO}_{4}$ (before and after heating at $100{ }^{\circ} \mathrm{C}$ for 5 minutes) and Dragendorff's spraying reagents.

\section{Plant material:}

Dovyalis caffra leaves and young stems were collected from Al-Orman Botanic Garden, Giza, Egypt in November 2015. A voucher herbarium specimen had been deposited in the Department of Pharmacognosy, Faculty of Pharmacy, Al-Azhar University, Nasr city, Cairo, Egypt.

\section{Extraction and isolation:}

The air-dried; finely powdered leaves and young stems of $D$. caffra $(2.5 \mathrm{Kg}$.) was exhaustively extracted with $70 \%$ methanol and evaporated under reduced pressure to yield $320 \mathrm{gm}$ of dark green semisolid residue (total methanolic extract).

\section{Separation of Purified Crude alkaloids and Isolation of Compound (1):}


About $100 \mathrm{gm}$ of the total extract was suspended in $1.5 \mathrm{~L}$ of $1 \%$ aqueous $\mathrm{H}_{2} \mathrm{SO}_{4}$, filtered, concentrated to $500 \mathrm{ml}$ (under reduced pressure), and then partitioned with petroleum ether $(500 \mathrm{ml} \times 3)$. The aqueous layer was separated, alkalinized with $25 \%$ $\mathrm{Na}_{2} \mathrm{CO}_{3}$ solution till $\mathrm{pH} 11.5$, and extracted with dichloromethane-DCM $(500 \mathrm{ml} \mathrm{x} 4)$. The DCM-layer was evaporated under reduced pressure to give $21.5 \mathrm{gm}$ of crude alkaloid extract. The crude alkaloid extract was dissolved in 500ml DCM and extracted with $10 \%$ aqueous acetic acid $(500 \mathrm{ml} \times 3)$. The acetic acid layer was concentrated (under reduced pressure), alkalinized with $\mathrm{Na}_{2} \mathrm{CO}_{3}$ powder (till no more effervescence), and extracted again with DCM $(500 \mathrm{ml} \times 4)$. The DCM-fraction was evaporated under reduced pressure to give $15 \mathrm{gm}$ of purified crude alkaloid extract (Alkaloid Fraction) (Yubin et al. 2014). The alkaloid fraction (12gm) was fractionated on silica gel vacuum liquid chromatography (VLC) using DCM-Methanol-Ammonia (100:0:0 - 50:50:1\%) to give eleven sub fractions; A-K. Sub fraction F was further chromatographed on silica gel column chromatography (CC) using DCM-Methanol-Ammonia (100:0:0 - 90:10:1\%) to afford compound 1 (eluted with 97:3:1\%), which was purified by prep. TLC using DCM-Methanol-Ammonia (95:5:1\%) to give $8 \mathrm{mg}$ of yellowish white residue (Comp.1). About 10gm of the total extract was suspended in $500 \mathrm{ml}$ dist. water and partitioned successively with petroleum ether, DCM, ethyl acetate, and n-butanol to give pet. ether fraction (2.4gm), DCM-fraction $(0.9 \mathrm{gm})$, EtOAc fraction $(0.5 \mathrm{gm})$, and $\mathrm{BuOH}$ fraction $(1.7 \mathrm{gm})$ for biological studies and GC/MS experiments.

\section{Isolation of Compounds (2) and (3):}

The methanolic extract (about 210gm) was suspended in distilled water and fractionated with DCM, EtOAc, and n-BuOH, respectively. The DCM fraction (50gm) was fractionated on silica gel vacuum liquid chromatography (VLC) using n-hexane-EtOAc to give fourteen sub fractions; A-N. Sub fraction D was further chromatographed on silica gel column chromatography (CC) using n-hexane-EtOAc to afford $12 \mathrm{mg}$ of compound (3) and $40 \mathrm{mg}$ of compound (2) respectively.

\section{Saponification of Pet. Ether Fraction:}

Pet. Ether Fr. (1gm) was refluxed with $50 \mathrm{ml}$ of $10 \%$ alcoholic $\mathrm{KOH}$ for 8 hours (till complete saponification). The alcohol was evaporated under reduced pressure, then the residue was suspended in $100 \mathrm{ml}$ distilled water, and extracted with DCM $(100 \mathrm{ml} \times 3)$.The DCM layer was concentrated to $100 \mathrm{ml}$, washed with dist. water several times to remove any alkalinity, dried with anhydrous $\mathrm{Na}_{2} \mathrm{SO}_{4}$, then evaporated under reduced pressure to give the unsaponifiable matter (UNSAP). The aqueous alkaline layer was acidified with dil. $\mathrm{HCl}(20 \mathrm{ml})$, and extracted with DCM. The DCM extract was washed with distilled water, dried with anhydous $\mathrm{Na}_{2} \mathrm{SO}_{4}$, and then evaporated under reduced pressure to give saponifiable matter (SAP), which was dissolved in $50 \mathrm{ml}$ absolute $\mathrm{MeOH}, 5 \mathrm{ml} \mathrm{Conc.} \mathrm{H}_{2} \mathrm{SO}_{4}$ was added, and then refluxed for 4 hours. After cooling and evaporation, 50ml distilled water was added and shaked well, then extracted with DCM, washed with distilled water, dried with anhydous $\mathrm{Na}_{2} \mathrm{SO}_{4}$, and then evaporated under reduced pressure to give methylated SAP fraction (El-Kashef et al. 2014). 


\section{Method of GC-MS analysis For SAP}

Mass spectra were recorded using Shimadzu GCMS-QP2010 (Tokyo, Japan) equipped with Rtx-5MS fused bonded column (30 m x $0.25 \mathrm{~mm}$ i.d. x $0.25 \mu \mathrm{m}$ film thickness) (Restek, USA) equipped with a split-splitless injector. The initial column temperature was kept at $70{ }^{\circ} \mathrm{C}$ for $2 \mathrm{~min}$. (isothermal) and programmed to $120{ }^{\circ} \mathrm{C}$ at a rate of $4{ }^{\circ} \mathrm{C} / \mathrm{min}$, and kept constant at $120^{\circ} \mathrm{C}$ for $2 \mathrm{~min}$. (isothermal) then programmed to $240{ }^{\circ} \mathrm{C}$ at a rate of $4{ }^{\circ} \mathrm{C} / \mathrm{min}$., and kept constant at $240{ }^{\circ} \mathrm{C}$ for $13 \mathrm{~min}$. (isothermal) . Injector temperature was $250{ }^{\circ} \mathrm{C}$. Helium carrier gas flow rate was $1.24 \mathrm{ml} / \mathrm{min}$. All the mass spectra were recorded applying the following condition: filament emission current, $60 \mathrm{~mA}$; ionization voltage, $70 \mathrm{eV}$; ion source, $230^{\circ} \mathrm{C}$. Diluted samples $(1 \% \mathrm{v} / \mathrm{v})$ were injected with split mode (split ratio 1: 20).

\section{Method of GC-MS analysis for UNSAP:}

Mass spectra were recorded using Shimadzu GCMS-QP2010 (Tokyo, Japan) equipped with Rtx-5MS fused bonded column $(30 \mathrm{~m}$ x $0.25 \mathrm{~mm}$ i.d. x $0.25 \mu \mathrm{m}$ film thickness) (Restek, USA) equipped with a split-splitless injector. The initial column temperature was kept at $50{ }^{\circ} \mathrm{C}$ for $3 \mathrm{~min}$. (isothermal) and programmed to $300{ }^{\circ} \mathrm{C}$ at a rate of $5{ }^{\circ} \mathrm{C} / \mathrm{min}$., and kept constant at $300{ }^{\circ} \mathrm{C}$ for $10 \mathrm{~min}$. (isothermal). Injector temperature was $280{ }^{\circ} \mathrm{C}$. Helium carrier gas flow rate was $1.37 \mathrm{ml} / \mathrm{min}$. All the mass spectra were recorded applying the following condition: filament emission current, $60 \mathrm{~mA}$; ionization voltage, $70 \mathrm{eV}$; ion source, $220^{\circ} \mathrm{C}$. Diluted samples $(1 \% \mathrm{v} / \mathrm{v})$ were injected with split mode (split ratio 1: 15).

\section{Compound 1:}

Yellowish-white powder, ${ }^{1} \mathrm{H}-\mathrm{NMR}\left(400 \mathrm{MHz}, C D C l_{3}\right), \delta 2.90(4 \mathrm{H}, \mathrm{m}, \mathrm{H}-2, \mathrm{H}-8)$, 1.24 (4H, m, H-3, H-7), 2.18 (4H, m, H-4, H-6), 1.5 (NH-5), 3.07 (2H, m, H-1'), 1.55 (2H, m, H-2'), $1.41\left(2 \mathrm{H}, \mathrm{m}, \mathrm{H}-3^{\prime}\right), 3.45\left(2 \mathrm{H}, \mathrm{m}, \mathrm{H}-4^{\prime}\right), 3.05\left(3 \mathrm{H}, \mathrm{s}, \mathrm{N}-\mathrm{CH}_{3}\right), 6.19(1 \mathrm{H}, \mathrm{d}, \mathrm{J}=14.5$ Hz, H-2'”), 6.85 (1H, dt, J=14.5,7.1 Hz, H-3' ), 2.18 (2H, m, H-4'”), $1.23-1.39$ (18H, m, H-5" to H-13' '), 0.88 (3H, t, J=7.1, H-14' '); APT-NMR (100 MHz, CDCl 3 ) $\delta 53.74(\mathrm{C}-2$, C-8), 32.03 (C-3, C-7), 45.14 (C-4, C-6), 53.81 (C-1'), 24.37 (C-2'), 28.45 (C-3'), 53.36 (C-4'), 167.51 (C-1' '), 119.81 (C-2' '), 147.80 (C-3' '), 32.69 (C-4' '), $29.36-29.80$ (C-5' to C-11',), 31.01 (C-12'), 22.79 (C-13'”), 14.22 (C-14'”), $35.56\left(\mathrm{~N}-\mathrm{CH}_{3}\right)$; ESI/MS m/z 408 $\left[\mathrm{M}^{+}+\mathrm{H}\right]\left(\right.$ calc. for $\left.\mathrm{C}_{25} \mathrm{H}_{49} \mathrm{~N}_{3} \mathrm{O}\right)$.

\section{Compound 2:}

White crystals, ${ }^{1} \mathrm{H}-\mathrm{NMR}\left(400 \mathrm{MHz}, C D C l_{3}\right), \delta 3.53(1 \mathrm{H}, \mathrm{m}, \mathrm{H}-3), 5.35(1 \mathrm{H}, \mathrm{m}, \mathrm{H}-$ 6), $0.68(3 \mathrm{H}, \mathrm{s}, \mathrm{H}-18), 1.01(3 \mathrm{H}, \mathrm{s}, \mathrm{H}-19), 0.92(3 \mathrm{H}, \mathrm{d}, J=6.5 \mathrm{~Hz}, \mathrm{H}-21), 0.81(3 \mathrm{H}, \mathrm{d}$, $J=6.5 \mathrm{~Hz}, \mathrm{H}-26), 0.83(3 \mathrm{H}, \mathrm{d}, J=6.5 \mathrm{~Hz}, \mathrm{H}-27), 0.84(3 \mathrm{H}, \mathrm{t}, J=7 \mathrm{~Hz}, \mathrm{H}-29)$; APT-NMR $(100$ $\left.\mathrm{MHz}, \mathrm{CDCl}_{3}\right) \delta 37.38(\mathrm{C}-1), 31.75(\mathrm{C}-2), 71.96$ (C-3), 42.41 (C-4), $140.88(\mathrm{C}-5), 121.88$ (C-6), 32.05 (C-7), 32.02 (C-8), 50.24 (C-9), 36.63 (C-10), 21.21 (C-11), 39.90 (C-12), 42.45 (C-13), 56.89 (C-14), 24.44 (C-15), 28.39 (C-16), 56.17 (C-17), 12.00 (C-18), 18.91 (C-19), 36.28 (C-20), 19.16 (C-21), 34.06 (C-22), 26.15 (C-23), 45.95 (C-24), 29.25 (C25), 19.97 (C-26), 19.54 (C-27), 23.18 (C-28), 12.12 (C-29); EI/MS m/z 414 [M] ${ }^{+}$(calc. for $\left.\mathrm{C}_{29} \mathrm{H}_{50} \mathrm{O}\right)$. 


\section{Compound 3:}

White amorphous powder, ${ }^{1} \mathrm{H}-\mathrm{NMR}\left(400 \mathrm{MHz}, C D C l_{3}\right), 3.67(2 \mathrm{H}, \mathrm{t}, J=6.6, \mathrm{H}-1)$, $2.04(1 \mathrm{H}$, brs, $\mathrm{OH}), 1.66-1.45(6 \mathrm{H}, \mathrm{m}, \mathrm{H}-2$ to $\mathrm{H}-4), 1.34-1.15(52 \mathrm{H}, \mathrm{m}, \mathrm{H}-5$ to $\mathrm{H}-30)$, $0.87(3 \mathrm{H}, \mathrm{t}, \mathrm{J}=7.1, \mathrm{H}-31)$; APT-NMR $\left(100 \mathrm{MHz}, C D C l_{3}\right) \delta 63.14(\mathrm{C}-1), 32.83(\mathrm{C}-2), 25.75$ (C-3), 29.69 (enormous peak; C-4 to C-28), 31.95 (C-29), 22.72 (C-30), 14.11 (C-31); EI/MS $m / z 452[\mathrm{M}]^{+}$(calc. for $\mathrm{C}_{31} \mathrm{H}_{64} \mathrm{O}$ ).

\section{Evaluation of cytotoxic activity:}

\section{Cytotoxic assay:}

The cytotoxic activity was measured in vitro on human cancer cell line (MCF-7, HCT-116 and HEP-G2) using Sulforhodamine B stain (SRB) assay applying the method of Skehan, et al. In this study the cytotoxic activities $\left(\mathrm{IC}_{50}\right)$ of various extracts $(70 \%$ methanol, petroleum ether, ethyl acetate, n-butanol and alkaloid fraction) from the leaves and young stems of Dovyalis caffra (Warb.) were measured against three different human cancer cell lines; breast adenocarcinoma (MCF-7); human colon carcinoma (HCT-116) and; hepatocellular carcinoma (HEP-G2). Cytotoxicity Assay by SRB method (Skehan et al. 1990) and the results were shown in table (3).

\section{Evaluation of Topoisomerase II Inhibition Activity:}

Alkaloid fraction and petroleum ether extract of Dovyalis caffra (Warb.) leaves and young stems were selected to be evaluated against topoisomerase II (MBS\#942146) using human DNA topoisomerase 2-beta (TOP2B) ELISA kit according to manufacturer's instructions. Prepare all reagents, working standards, and samples. Add $100 \mu \mathrm{l}$ of standard and sample per well and incubate for 2 hours at $37{ }^{\circ} \mathrm{C}$. Remove the liquid of each well, don't wash. Add $100 \mu \mathrm{l}$ of biotin-antibody to each well and incubate for 1 hour at $37{ }^{0} \mathrm{C}$. Aspirate each well and wash three times. Add $100 \mu \mathrm{l}$ of horseradish peroxidase (HRPavidin) to each well and incubate for 1 hour at $37{ }^{\circ} \mathrm{C}$. Repeat the aspiration/wash process for five times. Add $90 \mu \mathrm{l}$ of 3, 3', 5, 5'-Tetramethylbenzidine (TMB) substrate to each well and incubate for $15-30$ minutes at $37{ }^{0} \mathrm{C}$, protect from light. Add $50 \mu$ of stop solution to each well and determine the optical density of each well within 5 minutes, using a microplate reader set to $450 \mathrm{~nm}$. The values of $\%$ activity versus a series of extracts concentrations ranging from $0.01 \mu \mathrm{M}$ to $100 \mu \mathrm{M}$ (with semi-log decrease in concentration) were then plotted using non-linear regression analysis of sigmoidal dose response curve. The $\mathrm{IC}_{50}$ values for alkaloid fraction and petroleum ether extract against Topo II were determined by the concentration causing a half maximal percent activity and the data were compared with staurosporine as standard Topo II inhibitors (Abdelhaleem et al. 2018; Hassanin et al. 2018; Kassab and Gedawy 2018) and the results were shown in table (4).

\section{Evaluation of antimicrobial activity:}

The antimicrobial activity of different Dovyalis caffra extracts were tested against a range of micro-organisms including two Gram-positive bacteria (Staphylococcus aureus 'ATCC 25923' and Bacillus subtilis 'ATCC 6633'), two Gram-negative bacteria (Salmonella typhi 'ATCC 700931' and Escherichia coli 'ATCC 
25922') and one fungal species (Aspergillus niger 'ATCC 6275') using the agar well diffusion assay method (Liang et al. 2012) and the results were shown in (Table 5). All extracts were tested in concentration $50 \mathrm{mg} / \mathrm{ml}$ and the inhibition zone was measure around each well after $24 \mathrm{~h}$.

\section{Anti-inflammatory Activities:}

\section{Evaluation of Lipoxygenase Inhibition Activity (5-LOX):}

The inhibitory activity of the total methanolic and ethyl acetate extracts of $D$. caffra (Warb.) against zileuton of 5-LOX was evaluated by using 5- lipoxygenase assay kit (Catalog \# K980-100, Biovision incorporated). $\mathrm{IC}_{50}$ values of the tested extracts were carried out according to procedures and instructions given with the assay kit and in accordance to previously reported methods. Briefly, Test extract preparation: Dissolve the test compound in appropriate solvent. Prepare at such concentration so volume of test compound solution added to a well is no more than $2 \mu \mathrm{l}$ in the final $100 \mu \mathrm{l}$ reaction volume per well. Add $2 \mu$ test extract to each well of the 96 well white plate. For "Solvent Control", add $2 \mu \mathrm{l}$ of the solvent used to prepare test compound solution at its final concentration in test wells, and for "Inhibitor Control" add $2 \mu \mathrm{l}$ of Zileuton, the provided LOX inhibitor. Bring up the volume to $40 \mu \mathrm{l}$ in each well by adding $38 \mu \mathrm{l}$ of LOX Assay Buffer. For the "Enzyme Control" well, add $40 \mu 1$ LOX Assay Buffer to a well. Reaction Mix: Mix enough reagents for the number of assays to be performed. For each well, prepare $40 \mu \mathrm{l}$ Mix containing: $36 \mu \mathrm{LOX}$ Assay Buffer, $2 \mu 1$ LOX Probe, 2 $\mu 1$ 5-LOX Enzyme; Mix well and add Reaction Mix to wells containing the Enzyme Control, Inhibitor Control, "Solvent Control" and Test Extracts. Incubate plate at RT for 10 minutes before adding substrate. There should be no bubbles in the wells. LOX Substrate: Dilute the provided LOX substrate (12500 X) in LOX Assay Buffer using 1:25 dilution factor to obtain a $500 \mathrm{X}$ solution. Depending on the number of reactions to be performed, dilute the $500 \mathrm{X}$ solution in LOX Assay Buffer at 1:100 to get $5 \mathrm{X}$ solution. $20 \mu \mathrm{l}$ of $5 \mathrm{X}$ solution will be needed per reaction. Make up enough substrate depending on the number of reactions. Measurement: Start recording fluorescence at Ex/Em 500/536 nm on the second minute after the addition of the substrate at 30 second intervals for 10 - 20 minutes (Huang et al. 2019).

\section{Evaluation of Cyclooxygenase- 1 \& 2 Inhibition Activity (COX-1 \& COX-2):}

The COX-1 (human recombinant) and COX-2 (human recombinant) inhibitory assay was carried out for total methanolic and ethyl acetate extracts of D. caffra (Warb.) using a COX Inhibitor Screening Assay Kit (Cayman Chemicals, Ann Arbor, MI, USA), according to the manufacturer's protocol. Briefly, heme and COX enzymes, COX-1 and COX-2, respectively, were added to test tubes containing COX reaction buffer (0.1 M Tris- $\mathrm{HCl}$, pH 8.0, containing $5 \mathrm{mM}$ EDTA and $2 \mathrm{mM}$ phenol). The mixture was vortexed and exposed to either reaction buffer or serum sample for 10 minutes at $37^{\circ} \mathrm{C}$. Celecoxib, the selective COX-2 inhibitor, was used at a concentration corresponding to its reported $\mathrm{IC}_{50}$ concentration (Reddy et al. 2000)(165 nM for COX-1 
and $65.61 \mathrm{nM}$ for COX-2) as a positive control. Subsequently, arachidonic acid solution was added to start the cyclooxygenase reaction. After incubation for 2 minutes and 37 ${ }^{\circ} \mathrm{C} 1 \mathrm{M}$ hydrochloric acid was added to terminate the enzyme catalytic reaction followed by chemical reduction of prostaglandin (PG) $\mathrm{PGH}_{2}$ to $\mathrm{PGF}_{2 \alpha}$ with saturated stannous chloride solution for 5 minutes at room temperature. The reaction products were stable for 1 week at $0-4{ }^{\circ} \mathrm{C}$. The COX activity was measured based on the amount of $\mathrm{PGF}_{2 \alpha}$ generated in the reaction tube and detected by the enzyme immunoassay kit using a standard curve. The inhibitory activity before adding tested extracts was compared to the COX inhibition induced by the extracts supplementation. The difference was expressed as increase in COX inhibitory activity.

Statistical analysis (Wilcoxon matched pairs signed rank test) was performed using the Graph Pad prism software (Graph Pad Software Inc., San Diego, CA, USA). Significance was defined as $P<0.05$ (Schäfer et al. 2006).

\section{Results and discussion:}

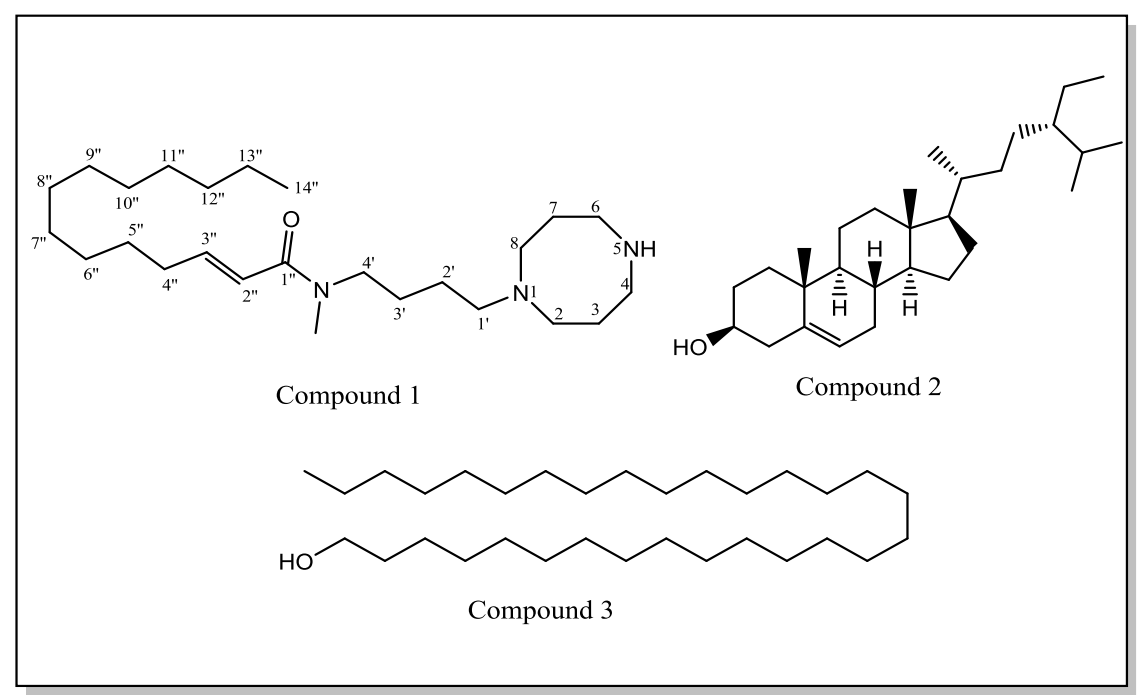

Figure 1: Compounds 1-3

Dovyalicin G; (E)-N-(4-(1,5-diazocan-1-yl)butyl)-N-methyltetradec-2-enamide (1): $\mathrm{R}_{\mathrm{f}}=$ 0.4, TLC solvent systems (DCM-MeOH-NH ${ }_{3}$ 95:5:0.1), gave positive result with Dragendorff's spraying reagent, obtained as yellowish-white powder displayed a molecular ion peak at $m / z 408\left[\mathrm{M}^{+}+\mathrm{H}\right]$. Other fragment ions at $m / z 336\left(\left(\mathrm{M}-\left(\mathrm{CH}_{2}\right)_{4} \mathrm{CH}_{3}\right)\right.$ (base peak)) and $\mathrm{m} / \mathrm{z} 265\left(\mathrm{M}-\left(\mathrm{CH}_{2}\right)_{9} \mathrm{CH}_{3}\right)$; suggesting a cleavage between $\mathrm{C}-4$ ' ' and C-5' to give resonance stabilized carbocation (allylic carbocation) (Hiserodt et al. 2004), in addition to $m / z, 113=\mathrm{C}_{6} \mathrm{H}_{13} \mathrm{~N}_{2}$; suggesting 1,5- diazocane ring attached to the side chain at the nitrogen of position number 1).

The ${ }^{1} \mathrm{H}$ NMR signals at $\delta 2.90$ (4H, m, H-2, H-8), 1.24 (4H, m, H-3, H-7), 2.18 (4H, m, H4, H-6), $1.5(1 \mathrm{H}$, brs, NH-5) and APT- NMR signals at $\delta 53.74$ (C-2, C-8), 32.03 (C-3, C$7), 45.14(\mathrm{C}-4, \mathrm{C}-6)$ suggesting the presence of $\mathrm{N}-\left(\mathrm{CH}_{2}-\mathrm{CH}_{2}-\mathrm{CH}_{2}\right)_{2}-\mathrm{NH}$ moiety (Pretsch et al. 2009). In addition to ${ }^{1} \mathrm{H}$ NMR signals at $\delta 3.07$ (2H, m, H-1'), 1.55 (2H, m, H-2'), 1.41 
(2H, m, H-3'), and 3.45(2H, m, H-4'), \& APT- NMR signals at $\delta 53.81$ (C-1'), 24.37 (C$\left.2^{\prime}\right), 28.45\left(\mathrm{C}-3^{\prime}\right)$, and $53.36\left(\mathrm{C}^{\prime} 4^{\prime}\right)$, which suggest the presence of $-\mathrm{N}-\left(\mathrm{CH}_{2}\right)_{4}-\mathrm{N}-$ moiety. The presence of three APT- NMR signals at about 53ppm; two of them was equivalent $(\delta$ 53.73) and one at $\delta 53.81$ indicating the presence of tertiary amine (in which the nitrogen atom attached to two equivalent carbons) (Pretsch et al. 2009). The previous data could be comply with 1,5-diazocane ring attached to butyl moiety at $\mathrm{N}-1$, which is the nucleus of Dovyalicin -type spermidine alkaloids isolated from the genus Dovyalis (Rasmussen et al. 2006; Stærk et al. 2003).

The ${ }^{1} \mathrm{H}$ NMR spectrum showed, also two olefinic protons; $\delta 6.19(1 \mathrm{H}, \mathrm{d}, J=14.5 \mathrm{~Hz}, \mathrm{H}-2$ '' $)$ and $6.85(1 \mathrm{H}, \mathrm{dt}, J=14.5,7.1 \mathrm{~Hz}, \mathrm{H}-3$ ''), which indicating two protons on a double bond with trans- coupling as displayed by $J$-value of $14.5 \mathrm{~Hz}$. The more down fielded proton at $\delta$ 6.85 is adjacent to $\mathrm{CH}_{2}$ (C-4') of the straight chain of the tetradec-2-enamide moiety as displayed by triplet of $J=7.1 \mathrm{~Hz}$, and signals at $\delta 2.18(2 \mathrm{H}, \mathrm{m}, \mathrm{H}-4$ ' '), $1.23-1.39(18 \mathrm{H}, \mathrm{m}$, $\mathrm{H}-5$ "' to H-13' '), 0.88 ( $3 \mathrm{H}, \mathrm{t}, J=7.1, \mathrm{H}-14$ ' ') also confirm this straight side chain. The APTNMR spectrum exhibited two olefinic carbon signals at $\delta 119.8$ (C-2''), and 147.8 (C-3''); suggesting a double bond adjacent to carbonyl group ( $\alpha \beta$ - unsaturated carbonyl moiety). The signal at $\delta 167 \mathrm{ppm}$ is typical for amide carbonyl group. Besides carbon signals of straight chain fatty acid residue at $\delta 32.7$ (C-4' '), $29.4-29.8$ (C-5' to C-11' '), 31.7 (C12 '), 22.8 (C-13'"), 14.2 (C-14''). The presence of singlet at $\delta 3.05$ in ${ }^{1} \mathrm{H}$ NMR spectrum and one methyl signal at $\delta 35.56$ in APT-NMR spectrum indicating the presence of $\mathrm{N}-\mathrm{CH}_{3}$. The structure of compound (1) was confirmed by 2D-NMR experiment (HMBC) as illustrated in figure 2 .

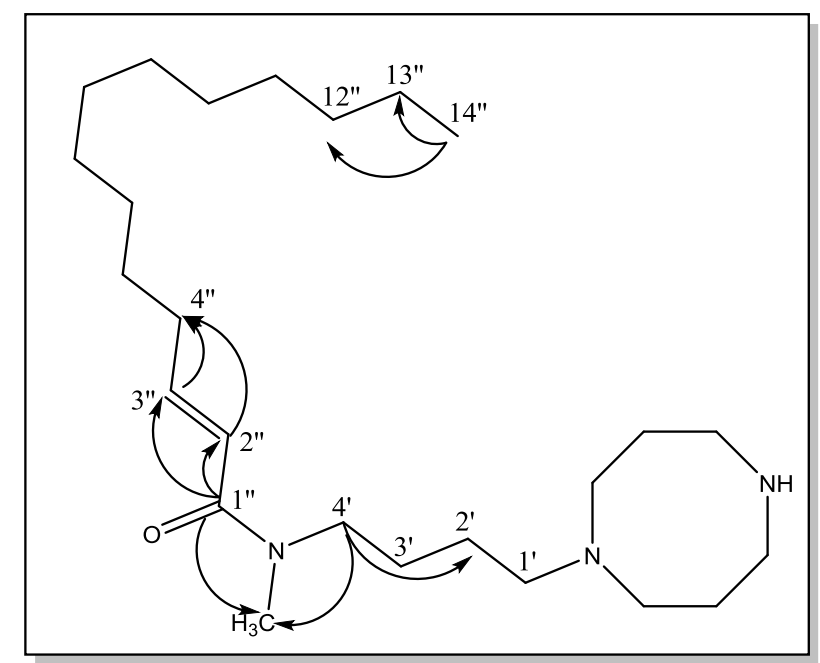

Figure 2: HMBC-correlations of Compound (1)

The HMBC (figure 2) showed the following correlations: C-1" correlates with both $\mathrm{H}$ 2 " and H-3" (confirming that the double bond is conjugated with the carbonyl group); the methyl protons of N-CH3 correlates with C-1"'; H-4' correlates with the carbon of $\mathrm{N}-\mathrm{CH} 3$ (confirming the position of $\mathrm{N}-\mathrm{CH} 3$ ) and $\mathrm{C}-2$ '; H-4', correlates with $\mathrm{C}-3$ ', and C-2"'; and finally methyl protons of C-14'" correlates with C-13' and C-14"'. 
Compound (2): By comparing the spectral data with that of the published literature (Aliba, Ndukwe, and Ibrahim 2018), the compound was identified as $\beta$-sitosterol which is previously isolated from the same plant (Sayed et al. 2000).

Compound (3): The spectral data of compound (3) was compared with that of published literature (Wang et al. 2006) and identified as Hentriacontan-1-ol. It is worth mentioning that this long chain fatty alcohol (Hentriacontan-1-ol) is first reported from the genus Dovyalis.

\section{GC/MS of Petroleum Ether Fraction (Lipoid Matter) of Dovyalis caffra:}

The results of GC/MS analysis of the saponifiable matter of $D$. caffra leaves and young stems shown in table (1) revealed the presence of 12 compounds from which four were identified as methyl esters of saturated fatty acids (63.77\%), three were identified as methyl esters of unsaturated fatty acids (19.94\%), one was identified as a saturated dicarboxylic acid methyl ester (9,12-Octadecadienoic acid methyl ester; 13.54\%) and one methoxylated fatty acid $(1.16 \%)$ whereas three compounds $(1.57 \%)$ couldn't be identified.

Palmitic acid (Hexadecanoic acid) methyl ester was the major identified fatty acid methyl ester (53.27\%) followed by linolenelaidic acid (9,12,15-(Z,Z,Z)Octadecatrienoic acid) methyl ester (16.68\%), linoleic acid (9,12-(Z,Z)-Octadecadienoic acid) methyl ester (13.54\%), stearic acid methyl ester (7.12\%), tetradecanoic acid methyl ester $(2.74 \%)$ and 2-(E)- Hexadecenoic acid methyl ester $(1.85 \%)$ while the other identified fatty acids methyl esters were in minor amounts.

Identification of the fatty acid methyl esters was done by comparison of their retention times and by matching their mass spectra with the national institute of standards and technology (NIST-11) library. 
Table 1: GC/MS of saponifiable matter of $D$. caffra leaves and young stems

\begin{tabular}{|c|c|c|c|c|}
\hline $\begin{array}{l}\text { Peak } \\
\text { No. }\end{array}$ & $\begin{array}{l}\text { Retention } \\
\text { Time } \\
\text { (min.) }\end{array}$ & Name & $\begin{array}{l}\text { Area } \\
(\%)\end{array}$ & $\begin{array}{l}\text { Base } \\
\text { Peak } \\
(\mathbf{m} / \mathbf{z})\end{array}$ \\
\hline 1 & 30.037 & Tetradecanoic acid methyl ester & 2.74 & 74.05 \\
\hline 2 & 35.450 & Unknown Compound & 0.29 & 43.00 \\
\hline 3 & 35.569 & Hexadecanoic acid methyl ester & 53.27 & 74.05 \\
\hline 4 & 36.875 & 2-(E)- Hexadecenoic acid methyl ester & 1.85 & 87.05 \\
\hline 5 & 38.085 & Heptadecanoic acid methyl ester & 0.64 & 74.05 \\
\hline 6 & 39.740 & 9,12-Octadecadienoic acid methyl ester & 13.54 & 67.05 \\
\hline 7 & 39.912 & $\begin{array}{l}\text { 9,12,15-(Z,Z,Z)- Octadecatrienoic acid methyl } \\
\text { ester }\end{array}$ & 16.68 & 79.05 \\
\hline 8 & 40.025 & Unknown Compound & 0.62 & 74.05 \\
\hline 9 & 40.479 & Methyl stearate & 7.12 & 74.05 \\
\hline $\mathbf{1 0}$ & 43.040 & 2-Methoxyoctanoic acid methyl ester & 1.16 & 129.15 \\
\hline 11 & 43.142 & $\begin{array}{l}\text { 9,12,15-(Z,Z,Z)-Octadecatrienoic acid methyl } \\
\text { ester }\end{array}$ & 1.41 & 87.10 \\
\hline 12 & 43.540 & Mixture of more than one compound & 0.66 & 69.10 \\
\hline
\end{tabular}

The results of the GC/MS analysis of the unsaponifiable matter of D. caffra leaves and young stems shown in table (2) revealed the presence of 5 compounds from which 3 (66.87\%) were identified whereas two compounds (33.13\%) couldn't be identified. The identified compounds were classified as fatty alcohols (mono- or polyhydric) (54.49\%), and steroids (45.51). $\beta$-sitosterol was the major identified compound from the unsaponifiable matter $(45.51 \%)$ followed by different mono- and polyhydric fatty alcohols (the exact structures were not confirmed for two of them $(33.13 \%)$ and the third was identified to be 3,7,11,15-Tetramethyl-2-hexadecen-1-ol (16.32\%)) and phytol $(5.04 \%)$. Phytol, which is an acyclic diterpene alcohol functions as a precursor for vitamin $\mathrm{E}$ and $\mathrm{K} 1$ and it has antioxidant and anticancer activities (El-Kashef et al. 2014).

Identification of the compounds was carried out by matching their retention times and by matching their mass spectra with the national institute of standards and technology (NIST-05) library. 
Table 2: GC/MS of unsaponifiable matter of $D$. caffra leaves and young stems

\begin{tabular}{|c|c|c|c|c|}
\hline $\begin{array}{l}\text { Peak } \\
\text { No. }\end{array}$ & $\begin{array}{l}\text { Retention } \\
\text { Time } \\
\text { (min.) } \\
\end{array}$ & Name & $\begin{array}{l}\text { Area } \\
(\%) \\
\end{array}$ & $\begin{array}{l}\text { Base Peak } \\
(\mathbf{m} / \mathbf{z})\end{array}$ \\
\hline 1 & 34.004 & Phytol & 5.04 & 71.05 \\
\hline 2 & 37.271 & 3,7,11,15-Tetramethyl-2-hexadecen-1-ol & 16.32 & 43.10 \\
\hline 3 & 52.539 & $\begin{array}{l}\text { Polyhydric fatty alcohol (the exact } \\
\text { structure is not confirmed) }\end{array}$ & 17.83 & 57.10 \\
\hline 4 & 55.342 & $\begin{array}{l}\text { Polyhydric fatty alcohol with isoprenoid } \\
\text { moiety (the exact structure is not } \\
\text { confirmed) }\end{array}$ & 15.30 & 57.05 \\
\hline 5 & 56.432 & $\beta$-Sitosterol & 45.51 & 43.05 \\
\hline
\end{tabular}

\section{Cytotoxic activity:}

All of Dovyalis caffra extracts showed promising activities against three cell lines (Table 3). Total extract, pet. ether fr. and alkaloid fr. were the most active against HEP-G2 and MCF-7 cell lines. Total extract, pet. ether fr. and $\mathrm{BuOH}$ fr. were the most active against HCT-116 cell line (Table 3 ). The promising activities pet. ether fr. and alkaloid fr. encourage us to explore mechanism of action of cytotoxicity by testing inhibition of activity of Topoisomerase II.

Table 3: $\mathrm{IC}_{50}$ in $\mu \mathrm{g} / \mathrm{ml}$ of different $D$. caffra extracts against the specified cell lines:

\begin{tabular}{cccc} 
& MCF-7 & HCT-116 & HEP-G2 \\
\hline Total Extract & $4.01 \pm 0.37$ & $2.24 \pm 0.24$ & $2.18 \pm 0.2$ \\
\hline Alkaloid Fraction & $3.87 \pm 0.3$ & $5.43 \pm 0.5$ & $3.25 \pm 0.31$ \\
\hline Pet. Ether Fraction & $3.87 \pm 0.31$ & $3.18 \pm 0.3$ & $2.25 \pm 0.21$ \\
\hline EtOAc Fraction & $11.13 \pm 1.12$ & $7.32 \pm 0.76$ & $5.41 \pm 0.47$ \\
\hline $\begin{array}{c}\text { BuOH Fraction } \\
\text { Topoisomerase II Inhibition Activity: }\end{array}$ & $4.21 \pm 0.46$ & $4.13 \pm 0.48$ & $3.74 \pm 0.28$
\end{tabular}

Topoisomerases are crucial enzymes that control the higher-order structural state of DNA. By selective cleaving, the problems of DNA are resolved by temporarily cleaving both strands of a DNA duplex to form a cleavage complex through which another DNA segment can be transported (Schoeffler and Berger 2008). Topoisomerases can be classified in two general categories, termed type I or type II, depending on whether one or both DNA strands of a single duplex are cleaved during a catalytic cycle, respectively (Deweese and Osheroff 2008). A variety of small-molecule agents capable of inducing such effects are widely prescribed as anti-cancer drugs which in turn increase the population of topoisomerase II (TOP2) breaking complexes, which leads to TOP2-mediated chromosome DNA cleavage and ultimately death of cancer cells (Pommier et al. 2010). 
Alkaloid and pet. ether fractions were selected (based on cytotoxic activities) to study their inhibition potential for topoisomerase II; TOP2B (Table 4). Both tested fractions showed inhibitory activities at the sub-micromolar level $\left(\mathrm{IC}_{50}=37\right.$ and 110 $\mathrm{nM}$, for alkaloid and petroleum ether fractions respectively). It is worth mentioning that the $\mathrm{IC}_{50}$ of alkaloid fraction was close to that of the standard (Staurosporine; $\mathrm{IC}_{50}=10$ $\mathrm{nM})$, suggesting that inhibition is one of the involved mechanisms of cytotoxicity.

Table 4: IC $_{50}$ of Topoisomerase II Inhibition for Alkaloid and Pet. Ether Fractions of D. caffra:

(TOP2B)

$\mathrm{IC}_{50}$ conc. $(\mathrm{nM})$

\begin{tabular}{lc}
\hline \multicolumn{1}{c}{ Petroleum Ether Fraction } & 110 \\
\hline Alkaloid Fraction & 37 \\
\hline Staurosporine (Reference Control) & 10 \\
Antimicrobial activities of the different extracts and purified alkaloid fraction of \\
Dovyalis caffra:
\end{tabular}

In the worldwide as well as in the developing countries, the most human died due to infectious bacterial diseases (Nathan 2004). The bacterial organisms including Gram-positive and Gram-negative bacteria like different species of Bacillus, Staphylococcus, Salmonella and E. coli are the main source to cause severe infections in human because these organisms have the ability to survive in harsh condition due to their multiple environmental habitats (Ahameethunisa and Hopper 2010).

Herein we demonstrate the antimicrobial activity of the total extract, alkaloid, petroleum ether, DCM, ethyl acetate, and n-butanol fractions of D. caffra. The different extracts of $D$. caffra were tested against a range of microorganisms including two Gram-positive, two Gram-negative bacetria and one fungal species using the agar well diffusion assay method and the results were shown in Table (5).

The alkaloid fraction was the most active against all tested microorganisms, $\mathrm{BuOH}$ fraction was active against gram-positive bacteria (Staph. aureus and B. subtilis) and the tested fungal species (A. niger), while it showed no activity against tested gramnegative bacteria. The total extract showed activity against both Staph. aureus and A.niger and DCM-fraction showed activity against A. niger only. On the other hand, pet. ether and EtOAc fractions showed no antimicrobial activity against any of the tested microorganisms. 
Table 5: Antimicrobial activity of Dovyalis caffra extracts and purified alkaloid fraction (zone of inhibition in $\mathrm{mm}$ )

\begin{tabular}{|c|c|c|c|c|c|c|}
\hline & & $\begin{array}{c}\text { Staphylococcus } \\
\text { aureus } \\
\text { (ATCC 25923) }\end{array}$ & $\begin{array}{c}\text { Bacillus } \\
\text { subtilis } \\
\\
\text { (ATCC } \\
\text { 6633) }\end{array}$ & $\begin{array}{c}\text { Salmonella } \\
\text { typhi } \\
\\
\text { (ATCC } \\
\text { 700931) }\end{array}$ & $\begin{array}{c}\begin{array}{c}\text { Escherichia } \\
\text { coli }\end{array} \\
\text { (ATCC } \\
\text { 25922) } \\
\end{array}$ & $\begin{array}{c}\text { Aspergillus } \\
\text { niger } \\
\text { (ATCC } \\
\text { 6275) }\end{array}$ \\
\hline \multirow{6}{*}{ 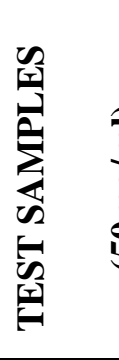 } & Total Extract & 22 & NA & NA & NA & 29 \\
\hline & $\begin{array}{l}\text { Alkaloid } \\
\text { Fraction }\end{array}$ & 24 & 17 & 15 & 14 & 30 \\
\hline & $\begin{array}{l}\text { Pet. Ether } \\
\text { Fraction }\end{array}$ & NA & NA & NA & NA & NA \\
\hline & DCM Fraction & NA & NA & NA & NA & 18 \\
\hline & EtOAc Fraction & NA & NA & NA & NA & NA \\
\hline & BuOH Fraction & 16 & 14 & NA & NA & 18 \\
\hline $\begin{array}{c}\text { Positive } \\
\text { control } \\
\text { For } \\
\text { Bacteria }\end{array}$ & $\begin{array}{c}\text { Gentamicin } \\
10 \mu \mathrm{g} / \mathrm{ml}\end{array}$ & 20 & 21 & 19 & 24 & \\
\hline $\begin{array}{c}\text { Positive } \\
\text { control } \\
\text { for fungi }\end{array}$ & $\begin{array}{c}\text { Fluconazole } \\
50 \mu \mathrm{g} / \mathrm{ml}\end{array}$ & & & & & 25 \\
\hline $\begin{array}{l}\text { Negative } \\
\text { control }\end{array}$ & DMSO & NA & NA & NA & NA & NA \\
\hline
\end{tabular}

\section{Anti-inflammatory Activities:}

Inflammation is caused by release of chemicals from tissues and migrating cells. Most strongly implicated are the prostaglandins (PGs), leukotrienes (LTs), histamine, bradykinin, in addition to more recent; platelet-activating factor (PAF) and interleukin1. Evidence for their involvement comes from studies with competitive antagonists for their receptors and inhibitors of their synthesis. $\mathrm{H}_{1}$ histamine antagonists are effective for hay fever and some skin allergies such as urticaria, which indicates the importance of histamine in these conditions. Symptoms of rheumatoid arthritis are alleviated by the aspirin-like anti-inflammatory drugs, which inhibit the cyclooxygenase enzyme and reduce synthesis of prostanoids. (Vane and Botting 1987).

The in vitro- anti-inflammatory activities of total methanolic and ethyl acetate extracts of $D$. caffra leaves and young stems were investigated via determination of cyclooxygenase-1 and -2 (COX-1 and COX-2) and 5-Lipoxygenase (5-LOX) inhibition activities. The selection of these two extracts for the study was based on folk medicine use of D. caffra and TLC profiling of different extracts of the plant. 


\section{Cyclooxygenase-1 and -2 (COX-1 and -2) inhibition activities:}

Cyclooxygenases (COX, also known as Prostaglandin H Synthase or PGHS) are responsible for the biosynthesis of PGs under acute inflammatory conditions (Blobaum and Marnett 2007; Xie et al. 1991). The induced COX-2 is believed to be the target enzyme for the anti-inflammatory activity of non- steroidal anti-inflammatory drugs (Blobaum and Marnett 2007).

The total methanolic and ethyl acetate extracts of $D$. caffra leaves and young stems COX-1 and 2 inhibition activity results are shown in table (6). Both tested extracts showed remarkable inhibitory activities for both enzymes. It is worth mentioning that the total methanolic extract of $D$. caffra is more selective toward COX2 as is expressed by selectivity ratio; which is the ratio between $\mathrm{IC}_{50}$ of $\mathrm{COX}-1$ and COX-2, expressing the affinity toward both enzymes $\left(\mathrm{IC}_{50}\right.$ for $\mathrm{COX}-1 / \mathrm{IC}_{50}$ for COX-2; 1.91) (Botting 2006); comparing with the ratio for the standard, celecoxib (selectivity ratio $=2.51)$.

Table 6: $\mathrm{IC}_{50}$ of COX-1 and 2 inhibition activities for total extract and EtOAc fraction of $D$. caffra:

\begin{tabular}{cccc} 
& COX-1 IC $_{\mathbf{5 0}}(\mathbf{n M})$ & $\mathbf{C O X}-\mathbf{2} \mathbf{I C}_{\mathbf{5 0}}(\mathbf{n M})$ & Selectivity ratio \\
\hline Total Extract & 151.38 & 79.28 & 1.91 \\
\hline EtOAc & 220.06 & 250.48 & 0.88 \\
Fraction & & & \\
\hline Celecoxib & 165 & 65.61 & 2.51
\end{tabular}

1. 5-Lipoxygenase (5-LOX) inhibition activities:

5-Lipoxygenase (5-LOX) is a non-heme iron-containing dioxygenase that converts unsaturated fatty acids to epoxides; for example the synthesis of leukotrienes from arachidonic acid. It is involved in processes like cell proliferation, differentiation and inflammation and has been implicated in inflammation and hyper proliferation mediated diseases like asthma, rheumatoid arthritis and cancer(Choi et al. 2008). The total methanolic and ethyl acetate extracts of D. caffra (Warb.) leaves and young stems were assayed for the 5-LOX inhibitory activity to complete the in vitro anti-inflammatory investigation, while the results showed weak activity comparing with the specified standard, zileuton (table 7).

Table 7: $\mathrm{IC}_{50}$ of 5-LOX inhibition activity for total extract and EtOAc fraction of D. caffra:

5-LOX IC 50 $_{\mathbf{5 0}}(\boldsymbol{\mu} \mathrm{M})$

\begin{tabular}{cc}
\hline Total Extract & $4.96 \pm 0.22$ \\
\hline EtOAc Fraction & $3.31 \pm 0.14$ \\
\hline Zileuton & 0.04
\end{tabular}




\section{REFERENCES:}

Abdelhaleem, Eman F, Mohammed K Abdelhameid, Asmaa E Kassab, and Manal M Kandeel. 2018. 'Design and synthesis of thienopyrimidine urea derivatives with potential cytotoxic and pro-apoptotic activity against breast cancer cell line MCF-7', European journal of medicinal chemistry, 143: 1807-25.

Ahameethunisa, Abdul R, and Waheeta Hopper. 2010. 'Antibacterial activity of Artemisia nilagirica leaf extracts against clinical and phytopathogenic bacteria', BMC complementary and alternative medicine, 10: 6 .

Aliba, MO, IG Ndukwe, and H Ibrahim. 2018. 'Isolation and characterization of Bsitosterol from methanol extracts of the stem bark of large-leaved rock fig (Ficus abutilifolia Miq)', Journal of Applied Sciences and Environmental Management, 22: 1639-42.

Blobaum, Anna L, and Lawrence J Marnett. 2007. 'Structural and functional basis of cyclooxygenase inhibition', Journal of medicinal chemistry, 50: 1425-41.

Botting, RM. 2006. 'Inhibitors of cyclooxygenases: mechanisms, selectivity and uses', Journal of physiology and pharmacology, 57: 113.

Chase, M. W., M. J. M. Christenhusz, M. F. Fay, J. W. Byng, W. S. Judd, D. E. Soltis, D. J. Mabberley, A. N. Sennikov, P. S. Soltis, and P. F. Stevens. 2016. 'An update of the Angiosperm Phylogeny Group classification for the orders and families of flowering plants: APG IV', Botanical Journal of the Linnean Society, 181: 1-20.

Chase, Mark W, Sue Zmarzty, M Dolores Lledo, Kenneth J Wurdack, Susan M Swensen, and Michael F Fay. 2002. 'When in doubt, put it in Flacourtiaceae: a molecular phylogenetic analysis based on plastid rbcL DNA sequences', Kew Bulletin, 57: 141-81.

Cheek, Martin, and Rita Ngolan. 2006. 'A reassessment of the Dovyalis spinosissima (Flacourtiaceae-Salicaceae) complex in Africa, with a new species from Cameroon', Kew Bulletin, 61: 595-600.

Choi, Jongkeun, Jae Kyung Chon, Sangsoo Kim, and Whanchul Shin. 2008. 'Conformational flexibility in mammalian 15S-lipoxygenase: reinterpretation of the crystallographic data', Proteins: Structure, Function, and Bioinformatics, 70: 1023-32.

Deweese, Joseph E, and Neil Osheroff. 2008. "The DNA cleavage reaction of topoisomerase II: wolf in sheep's clothing', Nucleic acids research, 37: 738-48.

El-Kashef, Dina, Ashraf Hamed, Hany Khalil, and Mohamed Kamel. 2014. Investigation of the Unsaponifiable and Saponifiable Matters of Pachypodium 
lamerei Drake Leaves and Stems by GC/MS (Journal of Pharmacognosy and Phytochemistry, 3(1), 128-132.

El-Menshawi, Bassem S, Walid Fayad, Khaled Mahmoud, Salwa M El-Hallouty, and May El-Manawaty. 2010. 'Screening of natural products for therapeutic activity against solid tumors'.

Hassanin, Hany M, Rabah AT Serya, Wafaa R Abd Elmoneam, and Mai A Mostafa. 2018. 'Synthesis and molecular docking studies of some novel Schiff bases incorporating 6-butylquinolinedione moiety as potential topoisomerase II $\beta$ inhibitors', Royal Society open science, 5, 1-13.

Hiserodt, Richard D, Barry M Pope, Michael Cossette, and Mark L Dewis. 2004. 'Proposed mechanisms for the fragmentation of doubly allylic alkenamides (tingle compounds) by low energy collisional activation in a triple quadrupole mass spectrometer', Journal of the American Society for Mass Spectrometry, 15: $1462-70$.

Huang, Yuanzheng, Bin Zhang, Jiaming Li, Huicai Liu, Yanchun Zhang, Zhang Yang, and Wandong Liu. 2019. 'Design, synthesis, biological evaluation and docking study of novel indole-2-amide as anti-inflammatory agents with dual inhibition of COX and 5-LOX', European Journal of Medicinal Chemistry, 181: $41-50$.

Kassab, Asmaa E, and Ehab M Gedawy. 2018. 'Novel ciprofloxacin hybrids using biology oriented drug synthesis (BIODS) approach: anticancer activity, effects on cell cycle profile, caspase- 3 mediated apoptosis, topoisomerase II inhibition, and antibacterial activity', European journal of medicinal chemistry, 150: 40318.

Lemke, David E. 1988. 'A synopsis of Flacourtiaceae', Aliso: A Journal of Systematic and Evolutionary Botany, 12: 29-43.

Liang, Hanqiao, Yongmei Xing, Juan Chen, Dawei Zhang, Shunxing Guo, and Chunlan Wang. 2012. 'Antimicrobial activities of endophytic fungi isolated from Ophiopogon japonicus (Liliaceae)', BMC complementary and alternative medicine, 12: 238 - 43.

Moustafa, Seham MA, Bassem M Menshawi, Gamila M Wassel, K Mahmoud, and MM Mounier. 2014. 'Screening of some plants in Egypt for their cytotoxicity against four human cancer cell lines', Int J Pharm Tech Res, 6: 1074-84.

Nathan, Carl. 2004. 'Antibiotics at the crossroads', Nature, 431: 899.

Pommier, Yves, Elisabetta Leo, HongLiang Zhang, and Christophe Marchand. 2010. 'DNA topoisomerases and their poisoning by anticancer and antibacterial drugs', Chemistry \& biology, 17: 421-33. 
Pretsch, Ernö, Phillippe Buehlmann, Christian Affolter, Ernho Pretsch, P Bhuhlmann, and C Affolter. 2009. Structure determination of organic compounds (Springer).

Rasmussen, Bonnie, Aimee-Justine Nkurunziza, Matthias Witt, Hellen A OketchRabah, Jerzy W Jaroszewski, and Dan Stærk. 2006. 'Dovyalicin-type spermidine alkaloids from Dovyalis species', Journal of Natural Products, 69: 1300-04.

Reddy, C Madhava, Vadiraja B Bhat, G Kiranmai, M Narsa Reddy, P Reddanna, and KM Madyastha. 2000. 'Selective inhibition of cyclooxygenase-2 by Cphycocyanin, a biliprotein from Spirulina platensis', Biochemical and biophysical research communications, 277: 599-603.

Sayed, HM, DW Bishay, SA Yousef, MS Kamel, and RM Abdel-Salam. 2000. 'Alkaloids from the leaves of Aberia caffra'.

Schäfer, Angelika, Zuzana Chovanová, Jana Muchová, Katarína Sumegová, Anna Liptáková, Zdeňka Ďuračková, and Petra Högger. 2006. 'Inhibition of COX-1 and COX-2 activity by plasma of human volunteers after ingestion of French maritime pine bark extract (Pycnogenol)', Biomedicine \& Pharmacotherapy, 60: 5-9.

Schoeffler, Allyn J, and James M Berger. 2008. 'DNA topoisomerases: harnessing and constraining energy to govern chromosome topology', Quarterly reviews of biophysics, 41: 41-101.

Skehan, Philip, Ritsa Storeng, Dominic Scudiero, Anne Monks, James McMahon, David Vistica, Jonathan T Warren, Heidi Bokesch, Susan Kenney, and Michael R Boyd. 1990. 'New colorimetric cytotoxicity assay for anticancerdrug screening', Journal of the National Cancer Institute, 82: 1107-12.

Stærk, Dan, Matthias Witt, Hellen A Oketch-Rabah, and Jerzy W Jaroszewski. 2003. 'A new class of spermidine-derived alkaloids', Organic Letters, 5: 279396.

Stanstrup, Jan, Anne-Mette Rusch, Sara Agnolet, Hasse B Rasmussen, Per Mølgaard, Johannes Van Staden, Gary I Stafford, and Dan Staerk. 2010. 'Itoside A and 4-hydroxytremulacin from Dovyalis caffra and Dovyalis zeyheri', Biochemical Systematics and Ecology, 38: 346 - 48.

Steyn, EMA, AE Van Wyk, and GF Smith. 2005. 'Ovule-to-seed development in Dovyalis caffra (Salicaceae: Flacourtieae) with notes on the taxonomic significance of the extranucellar embryo sac', Bothalia, 35: 101-08.

Vane, JOHN, and Regina Botting. 1987. 'Inflammation and the mechanism of action of anti-inflammatory drugs', The FASEB Journal, 1: 89-96. 
Wang, J. D., M. L. Dong, W. Zhang, X. Shen, and Yue-Wei Guo. 2006. 'Chemical constituents of mangrove plant Aegiceras corniculatum', Chinese Journal of Natural Medicines, 4: 275-77.

Xie, WL, Jeffrey G Chipman, Donald L Robertson, RL Erikson, and Daniel L Simmons. 1991. 'Expression of a mitogen-responsive gene encoding prostaglandin synthase is regulated by mRNA splicing', Proceedings of the National Academy of Sciences, 88: 2692-96.

Yubin, JI, Yu Miao, Wang Bing, and Zhang Yao. 2014. 'The extraction, separation and purification of alkaloids in the natural medicine', J Chem Pharm Res, 6: $338-45$.

Zaki, D. 1975. 'Biological investigation of Dovyalis caffra', Planta medica, 27: 330-32. 


\section{الملخص العربيى}

فصل قلويد جديد من نوع (دوفياليسين/ سبيرميدين) من نبات الدوفياليس كافرا المنتمى للعائلة

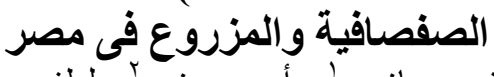

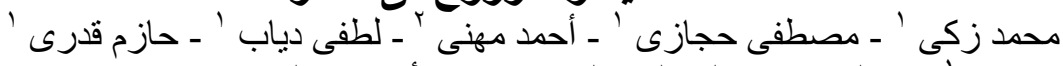

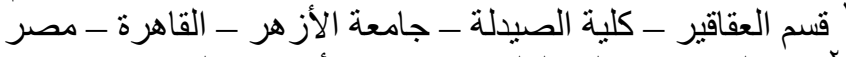

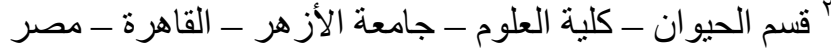

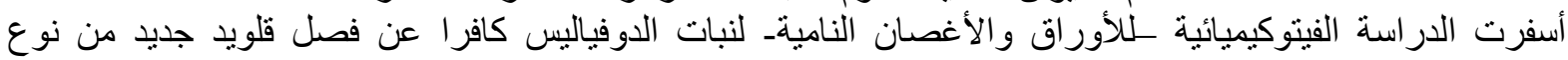

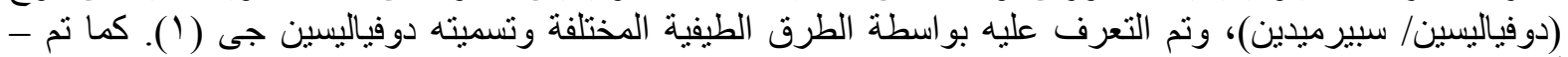

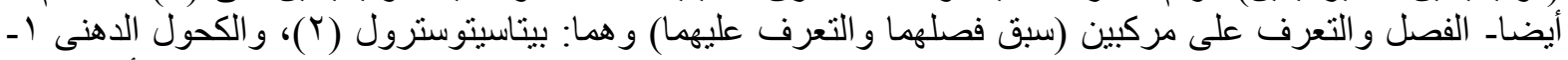

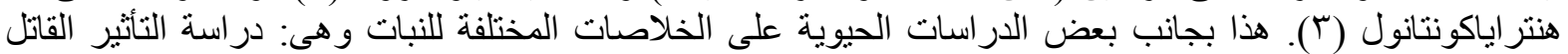

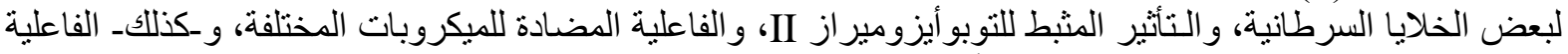

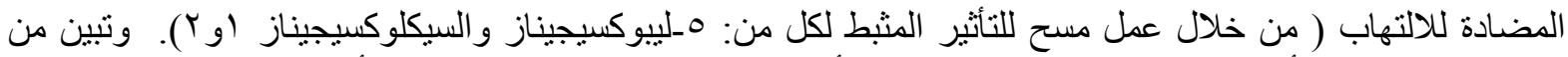

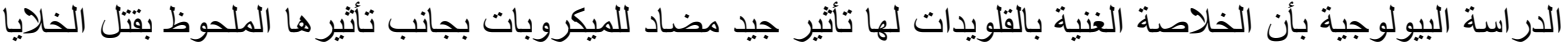
السرطانية و-كذلكـ تأثير ها المثبط للتوبو أيزوميراز II بينما الخلاصة الكحولية لها تأثير جيد كمثبط للسيكلوكسيجيناز

(وتحديدا سيكلو اوكسيجيناز 2). 